\title{
EFFECT OF STORAGE PERIOD ON ISOFLAVONE CONTENT AND PHYSIOLOGICAL QUALITY OF CONVENTIONAL AND TRANSGENIC SOYBEAN SEEDS ${ }^{1}$
}

\author{
MARIZANGELA RIZZATTI ÁVILA²; ALESSANDRO DE LUCCA BRACCINI"; LEANDRO PAIOLA ALBRECHT ${ }^{3}$; CARLOS ALBERTO \\ SCAPIM"; JOSÉ MARCOS GONTIJO MANDARINO, 5; GABRIEL LOLI BAZO ${ }^{6}$, YARA CAMILA FABRIN CABRAL7
}

\begin{abstract}
The objective in this research was to evaluate the isoflavone content and the physiological quality of seed from conventional and transgenic soybean cultivars before and after 180 days of storage. Twenty one soybean cultivars: CD 202, CD 206, CD 208, CD 213RR, CD 214RR, CD 215, CD 216, CD 217, CD 218, CD 221, BRS 184, BRS 185, BRS 214, BRS 244RR, BRS 245RR, BRS 246RR, BRS 255, BRS 257, BRS 258, BRS 261 and BRS 262, grown in the 2005/2006 crop season, were assayed. The seeds were packed in Kraft paper bags and stored at room temperature under laboratory conditions. Seeds were evaluated with respect to their germination and vigor (first germination count, accelerated aging and tetrazolium test) and their total isoflavone contents and respective aglycon forms (daidzein, genistein and glycitein),glycosides (daidzine, genistine and glycitine) and malonyl conjugates. A completely randomized block design with six replications with the treatments set out within a subplot scheme (21 cultivars $\mathrm{x} 2$ storage periods) was used. The F-test was used to compare means between storage periods and the Scott-Knott test to compare cultivars for each storage period, both with a $95 \%$ probability. It was concluded that isoflavone contents differ between cultivars and show a distinct behavior throughout storage.
\end{abstract}

Index terms: aglycon, Glycine max, daidzein, genistein, vigour.

\section{EFEITO DO PERIODO DE ARMAZENAMENTO NOS TEORES DE ISOFLAVONAS E NA QUALIDADE FISIOLÓGICA DE SEMENTES DE SOJA CONVENCIONAL E TRANSGÊNICA}

\begin{abstract}
RESUMO- Objetivou-se no presente trabalho avaliar o conteúdo de isoflavonas e a qualidade fisiológica de sementes de soja antes e após 180 dias de armazenamento. Para tal utilizou-se vinte e uma cultivares de soja CD 202, CD 206, CD 208, CD 213RR, CD 214RR, CD 215, CD 216, CD 217, CD 218, CD 221, BRS 184, BRS 185, BRS 214, BRS 244RR, BRS 245RR, BRS 246RR, BRS 255, BRS 257, BRS 258, BRS 261 e BRS 262 produzidas na safra 2005/2006 as quais foram acondicionadas em sacos de papel Kraft multifoliado e armazenadas em condições de ambiente natural de laboratório. As sementes foram avaliadas quanto a germinação, vigor (primeira contagem de germinação, envelhecimento acelerado e tetrazólio) e quanto ao teor de
\end{abstract}

\footnotetext{
${ }^{1}$ Submetido em 20/04/2010. Aceito para avaliação em 27/08/2010.

${ }^{2}$ Eng. Agr., Dra., Pesquisadora da Área de Propagação Vegetal, Instituto Agronômico do Paraná, Unidade Regional de Pesquisa Oeste, Estação Experimental de Santa Tereza do Oeste, Rodovia PRT 163 Km 188 Cruzinha, Caixa Postal: 2 CEP.: 85825-000, Santa Tereza do Oeste, PR; e-mail: marizangela_rizzatti@hotmail.com

${ }^{3}$ Eng. Agr., Dr., Prof. Adjunto do Depto. de Ciências Agronômicas, UEM. Estrada da Paca s/n. Bairro: São Cristovão, 87507-190, Umuarama, PR; e-mail: lpalbrecht@yahoo.com.br.
}

\begin{abstract}
${ }^{4}$ Eng. Agr., Dr., Prof. Associado do Depto. de Agronomia, UEM, Campus Universitário, Av. Colombo, 5.790, Bloco J45, $2^{\circ}$ andar. CEP.: 87020170, Maringá, PR; Bolsista do CNPq; e-mail: albraccini@uol.com.br

${ }^{5}$ Pesquisador do Centro Nacional de Pesquisa em Soja, Caixa Postal: 231, CEP.: 96001-970, Londrina, PR; e-mail: jmarcos@cnpso.embrapa.br

${ }^{6}$ Aluno de Graduação em Agronomia, Depto. de Agronomia, UEM, Maringá, PR; Bolsista PIBIC/CNPq; e-mail: gabriel.loli@ibest.com.br

${ }^{7}$ Aluna de Graduação em Agronomia, Depto. de Ciências Agronômicas, UEM.
\end{abstract}




\begin{abstract}
isoflavonas totais e suas respetivas formas agliconas (daidzeína, genisteína e gliciteína), glicosídeos (daidzina, genistina e glicitina) e seus conjugados malonil. O delineamento experimental utilizado foi o inteiramente casualizado com 6 repetições e tratamentos dispostos no esquema de parcelas subdivididas ( 21 cultivares $\times 2$ tempos de armazenamento). Para a comparação de médias entre tempos de armazenamento, utilizou-se o teste $\mathrm{F}$ e para comparações de cultivares para cada tempo de armazenamento utilizou-se o teste de agrupamento de Scott-Knott, ambos com 95\% de probabilidade. Pelos resultados foi possível concluir que os teores de isoflavonas diferenciam-se entre as cultivares e possuem comportamento distinto ao longo do armazenamento.
\end{abstract}

Termos para indexação: agliconas, Glycine max, daidzina, genistina, vigor.

\section{INTRODUCTION}

Soybean is an essential food, which provides proteins, saturated and unsaturated fatty acids and some vitamins, besides possessing polyphenolic compounds such as isoflavones.

Isoflavones comprise aglycons (daidizein, genistein and glycitein), the respective glycosides (daidzine, genistine and glycitine), as well as their malonyl- and acetyl-conjugates (Carrão-Panizzi, 1996). Genistin and daidzin comprise $50 \%$ to $90 \%$ of the flavonoids found in soyflour (Fukutake et al., 1996), while malonyl genistin and malonyl daidzin forms constitute around $66 \%$ of total isoflavones in mature soybean seeds (Kudou et al., 1991).

In seed tissue cells, the antioxidant effect is one of the main properties of isoflavones (Shahidi and Wanasundara, 1992) and could be an important warranty mechanism for seed quality, since the degradation of cell plasma membranes by free radicals is one of the most discussed and accepted theories of seed deterioration. Krzyzanowski et al. (2001) demonstrated that isoflavone content is related to high seed quality.

Several factors are linked to deterioration, including a decrease in enzyme activity; reduction in cell respiration and biosynthesis; and an increase in cellular and sub-cellular permeability followed by consequent mitochondrial degradation (França Neto and Henning, 1984).

Seed quality includes a group of characteristics which determines its value for sowing, and indicating that a seed's potential performance can only be consistently identified when an interaction of genetic, physical, physiological and health characteristics is considered (Hampton and Tekrony, 1995; Marcos Filho, 2005). Deterioration is a process which involves cytological, biochemical and physical changes, which eventually cause seed death. This deterioration process has been characterized by Delouche (1982) as inexorable and irreversible, dependent on the physiological maturation time and varying among seed lots of the same cultivar and species. This process is determined by genetic factors, stink bug attack, environmental conditions at the postmaturation/pre-harvest periods, harvest and processing procedures, as well as storage and transport conditions (Braccini et al., 2001).

Seeds' storage is accomplished right after seeds reach their physiological maturation stage even before harvesting (Vieira and Carvalho, 1994). Storage after harvest must be conducted in order to minimize as much as possible biochemical reactions, which cause physiological quality loss, provide unfavorable conditions or those ones that do not allow insects and fungi development which contributes to this reduction on quality (Villa et al., 1979). A lower storage potential leads to a higher seeds' deterioration, a decrease on germination percentage and an increase of abnormal seedlings' incidence (Delouche and Baskin, 1973).

The objective in this study was to evaluate isoflavone content as well as the physiological quality of soybean seeds before and after 180 days of storage.

\section{MATERIAL AND METHODS}

Laboratory evaluations were made at the Seed Technology Laboratory of the Applied Agricultural 
Research Nucleus (NUPAGRI) in the Agricultural Science Center of the State University of Maringá, Paraná, and also at EMBRAPA SOYBEAN (National Soybean Research Center) in Londrina, Paraná.

The soybean cultivars evaluated were: CD 202, CD 206, CD 208, CD 213 RR, CD 214 RR, CD 215, CD 216, CD 217, CD 218, CD 221, BRS 184, BRS 185, BRS 214, BRS 244 RR, BRS 245 RR, BRS 246 RR, BRS 255, BRS
257, BRS 258, BRS 261 and BRS 262 from COODETEC and EMBRAPA SOYBEAN, produced in the 2005/2006 crop season.

Seeds were packed in Kraft paper bags, then labeled, sealed and stored at room temperature in the laboratory with no control of atmospheric relative humidity and without light, from March to August, 2006, totaling up to 180 days of storage (Figure 1).

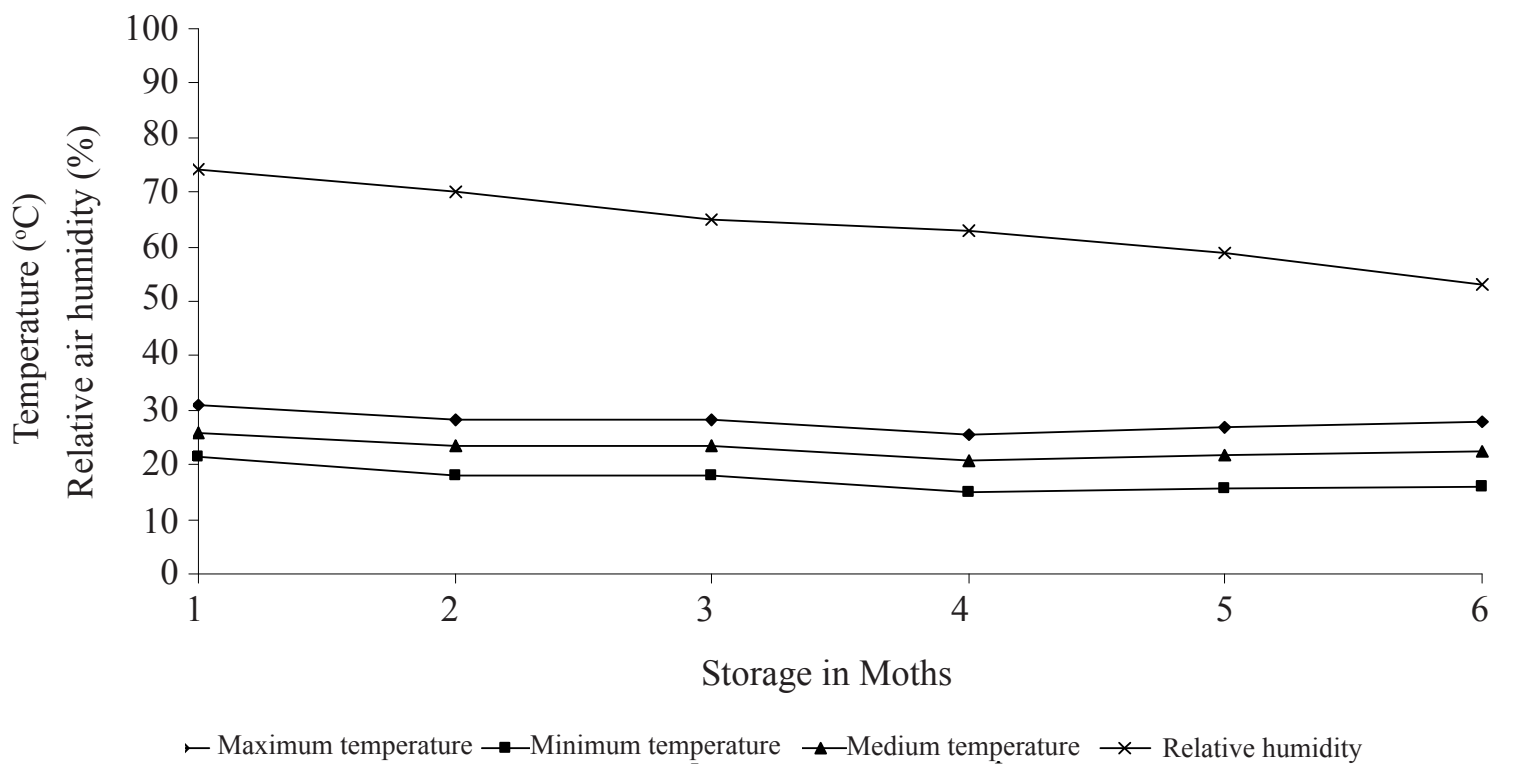

FIGURE 1. Temperature $\left({ }^{\circ} \mathrm{C}\right)$ and relative air humidity $(\%)$ during storage between March and August.

When stored, seeds had $12 \%$ water content, which is considered suitable for their conservation (Aguirre and Peske, 1992).

The experiment was set out in a completely randomized block design with six replications and the treatments in a subplots scheme ( 21 cultivars $\mathrm{x} 2$ storage periods).

Evaluations were made before storage (time zero) and after 180 days of storage for each soybean cultivar using the following tests:

Germination test: six replications of 50 seeds were placed between a three-leaf paper-towel imbibed in distilled water ( 3 times the dry paper weight) to germinate. They were then rolled up and placed in a Mangelsdorf germinator kept at a constant temperature of $25{ }^{\circ} \mathrm{C}$. Evaluations of the percentage of normal seedlings were made, both on the fifth (first count) and eighth (final count) days, after the beginning of the test, according to the established criteria of the Seed Analysis Rules (Brasil, 1992).
First count of the germination test: done together with the previous procedure, using the same methodology to assess the percentage of normal seedlings obtained on the fifth day after the beginning of the test (Brasil, 1992).

Accelerated aging test: six replications of 50 seeds were placed on stainless steel screens inside plastic boxes (gerbox) containing $40 \mathrm{~mL}$ water. The relative humidity inside the boxes was approximately 100\% according to the methodology described by Krzyzanowski et al. (1991). The boxes were then taken to a germination B.O.D-like chamber and kept at a constant temperature of $41{ }^{\circ} \mathrm{C}$ for 48 hours. After the aging period, the seeds were submitted to the germination test, as described previously. Germination was assessed on the fifth day after sowing and the percentage of seedlings considered normal was calculated (Marcos Filho, 1999).

Tetrazolium test: six replications of 50 seeds, which were osmoconditioned in paper towels imbibed 
in distilled water and placed in a germinator at a temperature of $25{ }^{\circ} \mathrm{C}$ for 16 hours. Seeds were then transferred to $50 \mathrm{~mL}$ plastic cups, and totally submerged in a $0.075 \%$ tetrazolium solution (2,3,5-triphenyl- $2 \mathrm{H}$ tetrazolium chloride) and kept at a temperature of $40{ }^{\circ} \mathrm{C}$ for 180 minutes inside a germination chamber in the absence of light. After the seed staining process, they were washed under running water and kept submerged until evaluation when they were individually sectioned longitudinally and symmetrically with a razor blade and classified according to the criteria proposed by França Neto et al. (1998). Viability was measured by the ratio of seeds belonging to classes 1 to 5; vigor level by classes 1 to 3 and viability loss by classes 6 to 8 . Both vigor and viability potentials were expressed as a percentage (França Neto et al., 1999).

Isoflavone content: soybean seeds were milled by using a knife Mill for 60 seconds at 17,000 r.p.m. Afterwards, $15 \mathrm{~g}$ of this flour was mixed with $50 \mathrm{~mL}$ of hexane constantly shaken for 24 hours at room temperature before being filtered to obtain non-fat soybean flour (FDS).

For isoflavone extraction, $100 \mathrm{mg}$ of this non-fat soybean flour was stored in assay tubes $(10 \mathrm{~mL})$ with 4 $\mathrm{mL}$ of ethanol solution $(70 \%)$ plus $0.1 \%$ of acetic acid and then sealed with a lid. The assay tubes were kept at room temperature for one hour and vigorously shaken every 15 minutes. Later, $2 \mathrm{~mL}$ of this extract were centrifuged at 15,000 r.p.m. for 4 minutes. The overfloating fractions obtained from this process were then transferred to tubes with the auto-injection system of a chromatographer, $40 \mu \mathrm{L}$ samples of the overfloating fractions were used for direct injections into the device. Each sample had six replications for analysis using high performance liquid chromatography (HPLC).

The separation and quantification of isoflavones were made according to the methodology described by Berhow (2002) using a Waters 2690 HPLC. A reversephase column ODS C18 (YMC Pack ODS-AM Columm) - $250 \mathrm{~mm}$ long $\mathrm{x} 0.4 \mathrm{~mm}$ internal width and $5 \mu \mathrm{m}$ particles - was used. The binary linear gradient system was used to separate the isoflavones. The mobile phases were: methanol with $0.025 \%$ of Trifluoroacetic acid (TFA) as solvent A and ultrapure deionized distilled water with $0.025 \%$ of TFA as solvent $\mathbf{B}$. The initial gradient was $20 \%$ for solvent $\mathbf{A}$, which reached $100 \%$ concentration in 40 minutes and immediately after that, it returned to $20 \%$ at 41 minutes, remaining steady until the end of the running
(60 minutes) for each sample. The mobile phase flow rate was $1 \mathrm{~mL} \mathrm{~min}^{-1}$ and the temperature during running was $25{ }^{\circ} \mathrm{C}$. Isoflavones were detected using a Waters 996 photodiode array detector, adjusted to a $260 \mathrm{~nm}$ wavelength. In addition, daidizin, daidzein, genistin and genistein standard operating protocols (Sigma Chemical Co.), solubilized in methanol (HPLC degree) were used at the following concentrations: $0.00625 \mathrm{mg} \cdot \mathrm{mL}^{-1} ; 0.0125$ $\mathrm{mg} \cdot \mathrm{mL}^{-1} ; 0.0250 \mathrm{mg} \cdot \mathrm{mL}^{-1} ; 0.05 \mathrm{mg} \cdot \mathrm{mL}^{-1}$ and 0.1000 $\mathrm{mg} \cdot \mathrm{mL}^{-1}$. Extreme standards were used as a reference as well as a molar extinction coefficient from each malonyl form to quantify them. The isoflavone content was calculated in milligrams per $100 \mathrm{~g}$ of soybean flour.

Statistical analysis: variance analysis of the results was made and when there was a significant interaction, were found the necessary partitioning was performed. Cultivar effects for each storage period were compared by the Scott-Knott (1974) grouping method while a comparison between storage periods for each cultivar was made using the F-test. All tests were calculated at the $5 \%$ probability level.

\section{RESULTS AND DISCUSSION}

Data on temperature and relative humidity during the storage period are shown in Figure 1. Average temperature during storage was $22.4^{\circ} \mathrm{C}$; average maximum temperature was $31.4{ }^{\circ} \mathrm{C}$ and average minimum temperature was 13.5 ${ }^{\circ} \mathrm{C}$. Average relative humidity during storage was $64 \%$. The result of variance analysis showed a significant interaction between cultivars $\mathrm{x}$ storage periods for all variables.

For the germination test (Table 1), the only cultivars which did not show any decrease in germination percentage during storage on first count (vigor) were the BRS 185 and BRS 244 RR cultivars. These cultivars maintained their performance at the final evaluation of the germination test, proving their high physiological potential.

The highest germination percentage at the beginning of storage was for the cultivars BRS 214, BRS 244 RR, BRS 246 RR and BRS 261 when initial germination was observed. These same genotypes continued to show the best performance even after storage, especially for cultivar BRS 244 RR, which had the best performance of all the materials tested. When seed quality was measured by the accelerated aging test (Table 1), all the cultivars were susceptible to storage and showed low germination percentages after storage. This highlights 
the consequences of the non-artificial storage conditions, which accelerated the deterioration process inherent in seed physiology (Delouche, 1982; Hampton and Tekrony,
1995; Marcos Filho, 2005). Therefore, it was confirmed that the exposure of seeds to aging resulted in a reduction in vigor, mainly after storage.

TABLE 1. Normal seedlings obtained from first and count of Germination test germination, and the accelerated aging test, using Twenty one soybean cultivars, before and after a 180 day storage period.

\begin{tabular}{|c|c|c|c|c|c|c|}
\hline \multirow{4}{*}{ Cultivar $^{1}$} & \multicolumn{2}{|c|}{ First count } & \multicolumn{2}{|c|}{ Germination test } & \multicolumn{2}{|c|}{ Accelerated aging } \\
\hline & \multicolumn{2}{|c|}{ Storage $^{2}$ (days) } & \multicolumn{2}{|c|}{ Storage $^{2}$ (days) } & \multicolumn{2}{|c|}{ Storage $^{2}$ (days) } \\
\hline & 0 & 180 & 0 & 180 & 0 & 180 \\
\hline & \multicolumn{2}{|c|}{--------- \% ----------- } & \multicolumn{2}{|c|}{-------- \% -------- } & \multicolumn{2}{|c|}{---------- \% ---------- } \\
\hline CD 202 & $76 \mathrm{Ba}$ & $40 \mathrm{Db}$ & $87 \mathrm{Aa}$ & $52 \mathrm{Cb}$ & $77 \mathrm{Ca}$ & $1 \mathrm{Db}$ \\
\hline CD 206 & $73 \mathrm{Ba}$ & $48 \mathrm{Cb}$ & $85 \mathrm{Aa}$ & $56 \mathrm{Cb}$ & $68 \mathrm{Da}$ & $12 \mathrm{Cb}$ \\
\hline CD 208 & $70 \mathrm{Ca}$ & $55 \mathrm{Bb}$ & $84 \mathrm{Aa}$ & $73 \mathrm{Bb}$ & $82 \mathrm{Ca}$ & $1 \mathrm{Db}$ \\
\hline CD 213 RR & $62 \mathrm{Da}$ & $32 \mathrm{Db}$ & $80 \mathrm{Ba}$ & $50 \mathrm{Cb}$ & $43 \mathrm{Fa}$ & $1 \mathrm{Db}$ \\
\hline CD 214 RR & $80 \mathrm{Ba}$ & $55 \mathrm{Bb}$ & $88 \mathrm{Aa}$ & $70 \mathrm{Bb}$ & $77 \mathrm{Ca}$ & $8 \mathrm{Db}$ \\
\hline CD 215 & $61 \mathrm{Da}$ & $27 \mathrm{~Eb}$ & $76 \mathrm{Ba}$ & $35 \mathrm{Db}$ & $56 \mathrm{Ea}$ & $1 \mathrm{Db}$ \\
\hline CD 216 & $74 \mathrm{Ba}$ & $56 \mathrm{Bb}$ & $82 \mathrm{Aa}$ & $67 \mathrm{Bb}$ & $67 \mathrm{Da}$ & $0 \mathrm{Db}$ \\
\hline CD 217 & $66 \mathrm{Ca}$ & $13 \mathrm{Fb}$ & $77 \mathrm{Ba}$ & $21 \mathrm{Db}$ & $78 \mathrm{Ca}$ & $0 \mathrm{Db}$ \\
\hline CD 218 & $67 \mathrm{Ca}$ & $18 \mathrm{Fb}$ & $78 \mathrm{Ba}$ & $32 \mathrm{Db}$ & $54 \mathrm{Ea}$ & $0 \mathrm{Db}$ \\
\hline CD 221 & $69 \mathrm{Ca}$ & $25 \mathrm{~Eb}$ & $84 \mathrm{Aa}$ & $36 \mathrm{Db}$ & $58 \mathrm{Ea}$ & $6 \mathrm{Db}$ \\
\hline BRS 184 & $50 \mathrm{Ea}$ & $23 \mathrm{~Eb}$ & $62 \mathrm{Ca}$ & $31 \mathrm{Db}$ & $59 \mathrm{Ea}$ & $0 \mathrm{Db}$ \\
\hline BRS 185 & $59 \mathrm{Da}$ & $54 \mathrm{Ba}$ & $74 \mathrm{Ba}$ & $68 \mathrm{Ba}$ & $94 \mathrm{Aa}$ & $22 \mathrm{Bb}$ \\
\hline BRS 214 & $88 \mathrm{Aa}$ & $60 \mathrm{Bb}$ & $95 \mathrm{Aa}$ & $78 \mathrm{Bb}$ & $81 \mathrm{Ca}$ & $13 \mathrm{Cb}$ \\
\hline BRS 244 RR & $90 \mathrm{Aa}$ & $89 \mathrm{Aa}$ & $94 \mathrm{Aa}$ & $92 \mathrm{Aa}$ & $90 \mathrm{Aa}$ & $30 \mathrm{Ab}$ \\
\hline BRS 245 RR & $59 \mathrm{Da}$ & $32 \mathrm{Db}$ & $74 \mathrm{Ba}$ & $52 \mathrm{Cb}$ & $57 \mathrm{Ea}$ & $0 \mathrm{Db}$ \\
\hline BRS 246 RR & $83 \mathrm{Aa}$ & $63 \mathrm{Bb}$ & $91 \mathrm{Aa}$ & $73 \mathrm{Bb}$ & $89 \mathrm{Ba}$ & $15 \mathrm{Cb}$ \\
\hline BRS 255 & $76 \mathrm{Ba}$ & $44 \mathrm{Cb}$ & $83 \mathrm{Aa}$ & $58 \mathrm{Cb}$ & $73 \mathrm{Ca}$ & $4 \mathrm{Db}$ \\
\hline BRS 257 & $78 \mathrm{Ba}$ & $37 \mathrm{Db}$ & $92 \mathrm{Aa}$ & $56 \mathrm{Cb}$ & $66 \mathrm{Da}$ & $2 \mathrm{Db}$ \\
\hline BRS 258 & $70 \mathrm{Ca}$ & $27 \mathrm{~Eb}$ & $80 \mathrm{Ba}$ & $49 \mathrm{Cb}$ & $73 \mathrm{Ca}$ & $6 \mathrm{Db}$ \\
\hline BRS 261 & $90 \mathrm{Aa}$ & $76 \mathrm{Ab}$ & 93 Aa & $86 \mathrm{Aa}$ & $87 \mathrm{Ba}$ & $20 \mathrm{Bb}$ \\
\hline BRS 262 & $67 \mathrm{Ca}$ & $21 \mathrm{~Eb}$ & $76 \mathrm{Ba}$ & $29 \mathrm{Db}$ & $62 \mathrm{Da}$ & $0 \mathrm{Db}$ \\
\hline C.V. (\%) Lot & \multicolumn{2}{|c|}{11.62} & \multicolumn{2}{|c|}{10.03} & \multicolumn{2}{|c|}{12.89} \\
\hline C.V. (\%) Sub-Lot & \multicolumn{2}{|c|}{10.89} & \multicolumn{2}{|c|}{9.23} & \multicolumn{2}{|c|}{9.63} \\
\hline
\end{tabular}

${ }^{1}$ Means followed by the same capital letter in each column belong to the same group according to the Scott-Knott grouping method (1974) at the 5\% probability level.

${ }^{2}$ Means followed by the same non-capital letter in each line do not differ from each other based on the F-test at the $5 \%$ probability level.

Degenerative alterations in the internal seed structures promote a breakdown in metabolism as well as the exchange of water and solutes between cells and the external environment, resulting in reduced seed viability (Vieira and Carvalho, 1994). According to Delouche and Baskin
(1973), the seed aging process leads to a destructuring of the cell membrane system mainly due to the action of highreactivity chemical groups called free radicals.

Regarding the differences between cultivars, the result from the BRS 244 RR cultivar was significant 
since it had the highest germination percentage even after the high temperature and moisture stresses of the aging test both before and after storage, thus demonstrating its high physiological quality compared to other cultivars.

Results from the tetrazolium test on $1-3$ and 1 - 5 (Table 2) also confirmed the superiority of the BRS 244 RR cultivar compared to most cultivars, not only for vigor potential but also for viability. This test showed that that CD 215 and BRS 245 RR cultivars had the lowest performance. The tetrazolium test, as an indicator of viability (1 - 5) as well as of vigor, confirmed the results observed for the germination (initial and final) and accelerated aging tests, where the results obtained before storage were higher than those after storage. The only deviation from this tendency was for the tetrazolium test, where the seed physiological quality of the BRS 262 cultivar showed higher values after 180 days of storage. Since this was only observed for this cultivar, it may be due to sampling but should be more carefully investigated in the future

TABLE 2. Vigour potential (1 - 3) and viability (1 - 5), measured by the tetrazolium test and total isoflavones of twenty-one soybean cultivars, before and after a 180 day storage period.

\begin{tabular}{|c|c|c|c|c|c|c|}
\hline \multirow{4}{*}{ Cultivar $^{1}$} & \multirow{2}{*}{\multicolumn{2}{|c|}{$\begin{array}{c}\text { Tetrazolium }(1-3) \\
\text { Storage }^{2} \text { (days) }\end{array}$}} & \multirow{2}{*}{\multicolumn{2}{|c|}{$\frac{\text { Tetrazolium }(1-5)}{\text { Storage }^{2} \text { (days) }}$}} & \multirow{2}{*}{\multicolumn{2}{|c|}{$\begin{array}{c}\text { Total of Isoflavones } \\
\text { Storage }^{2} \text { (days) }\end{array}$}} \\
\hline & & & & & & \\
\hline & 0 & 180 & 0 & 180 & 0 & 180 \\
\hline & \multicolumn{2}{|c|}{ - - } & \multicolumn{2}{|c|}{-------- \% ------- } & \multicolumn{2}{|c|}{$\mathrm{mg} 100 \mathrm{~g}^{-1}$ of flour } \\
\hline CD 202 & $61 \mathrm{Da}$ & $47 \mathrm{Db}$ & $82 \mathrm{Ba}$ & $77 \mathrm{Ca}$ & $310 \mathrm{Ea}$ & $246 \mathrm{~Gb}$ \\
\hline CD 206 & $66 \mathrm{Da}$ & $64 \mathrm{Ba}$ & $78 \mathrm{Ca}$ & $83 \mathrm{Ba}$ & $152 \mathrm{Jb}$ & $181 \mathrm{Ja}$ \\
\hline CD 208 & $75 \mathrm{Ca}$ & $55 \mathrm{Cb}$ & $85 \mathrm{Ba}$ & $81 \mathrm{Ba}$ & $247 \mathrm{Ha}$ & $239 \mathrm{Ha}$ \\
\hline CD 213 RR & $56 \mathrm{Da}$ & $58 \mathrm{Ca}$ & $84 \mathrm{Ba}$ & $80 \mathrm{Ba}$ & $213 \mathrm{Ia}$ & $199 \mathrm{Ib}$ \\
\hline CD 214 RR & $71 \mathrm{Ca}$ & $55 \mathrm{Cb}$ & $83 \mathrm{Ba}$ & $70 \mathrm{Db}$ & $356 \mathrm{Cb}$ & $420 \mathrm{Ba}$ \\
\hline CD 215 & $49 \mathrm{Ea}$ & $51 \mathrm{Ca}$ & $67 \mathrm{Db}$ & $76 \mathrm{Ca}$ & $302 \mathrm{Ea}$ & $305 \mathrm{Ea}$ \\
\hline CD 216 & $60 \mathrm{Da}$ & $56 \mathrm{Ca}$ & $78 \mathrm{Ca}$ & $76 \mathrm{Ca}$ & $277 \mathrm{Ga}$ & $199 \mathrm{Ib}$ \\
\hline CD 217 & $57 \mathrm{Da}$ & $58 \mathrm{Ca}$ & $73 \mathrm{Cb}$ & $82 \mathrm{Ba}$ & $301 \mathrm{Ea}$ & $278 \mathrm{Fb}$ \\
\hline CD 218 & $58 \mathrm{Da}$ & $63 \mathrm{Ba}$ & $75 \mathrm{Cb}$ & $83 \mathrm{Ba}$ & $258 \mathrm{Ha}$ & $233 \mathrm{Hb}$ \\
\hline CD 221 & $58 \mathrm{Da}$ & $44 \mathrm{Db}$ & $82 \mathrm{Ba}$ & $73 \mathrm{Cb}$ & $153 \mathrm{Ja}$ & $86 \mathrm{Mb}$ \\
\hline BRS 184 & $59 \mathrm{Da}$ & $44 \mathrm{Db}$ & $79 \mathrm{Ca}$ & $65 \mathrm{Db}$ & $276 \mathrm{Ga}$ & $251 \mathrm{~Gb}$ \\
\hline BRS 185 & $85 \mathrm{Ba}$ & $64 \mathrm{Bb}$ & $94 \mathrm{Aa}$ & $85 \mathrm{Bb}$ & $330 \mathrm{Da}$ & $327 \mathrm{Da}$ \\
\hline BRS 214 & $80 \mathrm{Ba}$ & $80 \mathrm{Aa}$ & $88 \mathrm{Aa}$ & $90 \mathrm{Aa}$ & $286 \mathrm{Fb}$ & $327 \mathrm{Da}$ \\
\hline BRS 244 RR & $95 \mathrm{Aa}$ & $84 \mathrm{Ab}$ & $95 \mathrm{Aa}$ & $91 \mathrm{Aa}$ & $507 \mathrm{Aa}$ & $327 \mathrm{Db}$ \\
\hline BRS 245 RR & $45 \mathrm{Ea}$ & $39 \mathrm{Da}$ & $64 \mathrm{Da}$ & $68 \mathrm{Da}$ & $414 \mathrm{Ba}$ & $345 \mathrm{Cb}$ \\
\hline BRS 246 RR & $84 \mathrm{Ba}$ & $58 \mathrm{Cb}$ & $93 \mathrm{Aa}$ & $77 \mathrm{Cb}$ & $260 \mathrm{Hb}$ & $290 \mathrm{Fa}$ \\
\hline BRS 255 & $70 \mathrm{Ca}$ & $57 \mathrm{Cb}$ & $88 \mathrm{Aa}$ & $67 \mathrm{Db}$ & $152 \mathrm{Ja}$ & $123 \mathrm{Lb}$ \\
\hline BRS 257 & $66 \mathrm{Da}$ & $56 \mathrm{Cb}$ & $82 \mathrm{Ba}$ & $73 \mathrm{Cb}$ & $304 \mathrm{~Eb}$ & $326 \mathrm{Da}$ \\
\hline BRS 258 & $74 \mathrm{Ca}$ & $71 \mathrm{Ba}$ & $94 \mathrm{Aa}$ & $89 \mathrm{Aa}$ & $163 \mathrm{Ja}$ & $168 \mathrm{Ka}$ \\
\hline BRS 261 & $69 \mathrm{Da}$ & $60 \mathrm{Cb}$ & $89 \mathrm{Aa}$ & $75 \mathrm{Cb}$ & $259 \mathrm{Hb}$ & $307 \mathrm{Ea}$ \\
\hline BRS 262 & $59 \mathrm{Db}$ & $67 \mathrm{Ba}$ & $76 \mathrm{Cb}$ & $86 \mathrm{Ba}$ & $411 \mathrm{Bb}$ & $533 \mathrm{Aa}$ \\
\hline C.V. (\%) Lot & \multicolumn{2}{|c|}{8.69} & \multicolumn{2}{|c|}{6.96} & \multicolumn{2}{|c|}{3.23} \\
\hline C.V. (\%) Sub-Lot & \multicolumn{2}{|c|}{7.96} & \multicolumn{2}{|c|}{8.34} & \multicolumn{2}{|c|}{4.23} \\
\hline
\end{tabular}

${ }^{1}$ Means followed by the same capital letter in each column belong to the same group, according to the Scott-Knott grouping method (1974) at the $5 \%$ probability level.

${ }^{2}$ Means followed by the same non-capital letter in each line do not differ from each other based on the F-test at the 5\% probability level. 
The results of our study agreed with those of other studies, in that total isoflavone content (Table 2) showed a significant difference $(P<0.05)$ between genotypes (Park et al., 2001). Overall, all cultivars showed a higher total isoflavone content before storage. Nevertheless, exceptions were observed for cultivars CD 206, CD 214 RR, BRS 214, BRS 246 RR, BRS 257, BRS 261 and BRS 262 where greater isoflavone content was observed after storage. This may be a result of the action of active cell repair agents.

The highest total isoflavone content before storage was observed in cultivar BRS 244 RR, which stood out because of its higher total isoflavone content after storage. This may be related to the high physiological potential of the seeds (Ávila, 2004) due to the antioxidant activities of isoflavones (Shahidi and Wanasundara, 1992; Esaki et al., 1998; Aguiar, 2002) and a possible phytoalexin action of isoflavonoids as a defense against pathogens (Yoshikawa et al., 1978; Pelicice et al., 2000), which permitted a delay in the post-harvest deterioration process and also during storage.

The lowest isoflavone contents before and after storage were predominantly identified for the conventional cultivars CD 206, CD 221, BRS 255, before storage and for BRS 255, BRS 258, CD 221 after storage. There is no relationship between the transgeny for glyphosate resistance and the increase in isoflavone content. It is known that alterations in metabolism may occur (Jaworski, 1972; Duke et al., 2003) and isoflavonoids are derived from secondary metabolism in crops (Taiz and Zeiger, 2004).

Isoflavone contents may be specifically associated with the physiological quality of seeds considering the deterioration process measured from the accelerated aging test. The lowest isoflavone contents for cultivars, such as BRS 258 and CD 221 can be related to low physiological potential, especially after 180 days of storage (Table 2).

The isoflavones identified in seeds are given in Tables 3 (aglycons), 4 (malonyl) and 5 (glycosil), revealing differences among genotypes as recorded in the literature (Park et al., 2001 and Carrão-Panizzi et al., 2003).

The highest aglycons content before storage was shown by the following cultivars: CD 208 (daidzein, glicitein and genistein); CD 213 RR (glicitein); BRS 184 (genistein). The highest aglycons content after storage: CD 206 (daidzein and glicitein); CD 217 and
CD 262 (genistein). Superior malonyl contents before storage: BRS 244 RR (daidzin and genistin); CD 217 (glicitin). The highest malonyl contents after storage: BRS 262 (daidzin and genistin); CD 214 RR (glicitin). Regarding glycosil contents before storage, the highest values were found in cultivars: BRS 245 RR (daidzin); CD 217 (glicitin); BRS 262 (genistin) and after storage: BRS 262 (daidzin, glicitin and genistin); CD 214 RR (glicitin).

Results like the ones above are useful considering the pharmacological interest in the search for the beneficial health care properties provided by isoflavonoids (Naim et al., 1974; Murphy, 1982; Coward et al., 1993; Miyazawa et al., 1999). Also, crop improvement and increased crop yield can supply a higher market demand.

Focusing on seed quality, malonyl content may be more related to increments in seed physiological potential (BRS $244 \mathrm{RR}$ ). This is logical when comparing low malonyl content with inferior physiological quality. This is observed for cultivars CD 215, CD 217, CD 218, CD 221, BRS 184 and BRS 255, when the storage time is compared.

Overall, the post-storage contents of malonyl and glycosil were higher than before storage, while aglycons tended to decrease during storage. This fact has demonstrated the possibility of a higher expression of malonyl and glycosil contents during storage and also their potential action as antioxidants and phytoalexins.

Importance should be given to the antioxidant activity since Park et al. (2001) demonstrated the possibility of flavonoid biosynthesis and interconversion from one form to another via enzymatic processes in an antioxidative action on free radicals.

The storage conditions, to which seeds were submitted, such as at non-climatized (natural) room temperatures, can lead to a deterioration process caused by high temperatures or temperature oscillations and moisture (Bewley and Black, 1985), as shown in Figure 1. Thus, alterations can occur to seeds during storage, including genetic injuries, loss of membrane system integrity, decrease of selective capacity, peroxidation of lipids, lixiviation of solutes, changes in seed respiratory activity, modification of enzyme activity and protein synthesis. The inability to maintain the electrochemical gradient, loss of cell compartmentalization, as well as the accumulation of toxic substances, consequently leads to physiological alterations such as: germination delay, decrease in tolerance to suboptimum environmental conditions 
during germination, reduction in growth and/or seedling vigor, increase in abnormal seedlings, higher susceptibility to pathogenic microorganism attack, irregular emergence, yield reduction, complete loss of germination capacity and seed death (Wilson and Mcdonald, 1986; Basavarajappa et al., 1991).

TABLE 3. Aglycone isoflavone content of seeds from Twenty one soybean cultivars, before and after a 180 day storage period.

\begin{tabular}{|c|c|c|c|c|c|c|}
\hline \multirow{4}{*}{ Cultivar $^{1}$} & \multicolumn{2}{|c|}{ Daidzein } & \multicolumn{2}{|c|}{ Glicitein } & \multicolumn{2}{|c|}{ Genistein } \\
\hline & \multicolumn{2}{|c|}{ Storage $^{2}$ (days) } & \multicolumn{2}{|c|}{ Storage $^{2}$ (days) } & \multicolumn{2}{|c|}{ Storage $^{2}$ (days) } \\
\hline & 0 & 180 & 0 & 180 & 0 & 180 \\
\hline & \multicolumn{2}{|c|}{ mg. $100 \mathrm{~g}^{-1}$ of flour } & \multicolumn{2}{|c|}{ mg. $100 \mathrm{~g}^{-1}$ of flour } & \multicolumn{2}{|c|}{$\mathrm{mg} .100 \mathrm{~g}^{-1}$ of flour } \\
\hline CD 202 & $5 \mathrm{Ea}$ & $4 \mathrm{Da}$ & $0 \mathrm{Ca}$ & $0 \mathrm{Ba}$ & $5 \mathrm{Fa}$ & $4 \mathrm{Cb}$ \\
\hline CD 206 & $2 \mathrm{Fb}$ & $30 \mathrm{Aa}$ & $0 \mathrm{Cb}$ & $2 \mathrm{Aa}$ & $2 \mathrm{Ia}$ & $2 \mathrm{Da}$ \\
\hline CD 208 & $15 \mathrm{Aa}$ & $3 \mathrm{Db}$ & $9 \mathrm{Aa}$ & $1 \mathrm{Ab}$ & $10 \mathrm{Aa}$ & $4 \mathrm{Cb}$ \\
\hline CD 213 RR & $5 \mathrm{Ea}$ & $3 \mathrm{Da}$ & $8 \mathrm{Aa}$ & $2 \mathrm{Ab}$ & $6 \mathrm{Ha}$ & $3 \mathrm{Da}$ \\
\hline CD 214 RR & $5 \mathrm{Ea}$ & $5 \mathrm{Ca}$ & $0 \mathrm{Cb}$ & $1 \mathrm{Aa}$ & $5 \mathrm{Fa}$ & $5 \mathrm{Ba}$ \\
\hline CD 215 & $7 \mathrm{Da}$ & $5 \mathrm{Ca}$ & $0 \mathrm{Cb}$ & $1 \mathrm{Aa}$ & $4 \mathrm{Ga}$ & $5 \mathrm{Ba}$ \\
\hline CD 216 & $7 \mathrm{Da}$ & $3 \mathrm{Db}$ & $0 \mathrm{Ca}$ & $1 \mathrm{Aa}$ & $6 \mathrm{Ea}$ & $2 \mathrm{Db}$ \\
\hline CD 217 & $7 \mathrm{Da}$ & $5 \mathrm{Cb}$ & $0 \mathrm{Ca}$ & $0 \mathrm{Ba}$ & $8 \mathrm{Ca}$ & $6 \mathrm{Ab}$ \\
\hline CD 218 & $7 \mathrm{Da}$ & $4 \mathrm{Db}$ & $0 \mathrm{Ca}$ & $0 \mathrm{Ba}$ & $9 \mathrm{Ba}$ & $4 \mathrm{Bb}$ \\
\hline CD 221 & $5 \mathrm{Ea}$ & $1 \mathrm{Fb}$ & $0 \mathrm{Ca}$ & $0 \mathrm{Ba}$ & $4 \mathrm{Ga}$ & $1 \mathrm{~Eb}$ \\
\hline BRS 184 & $12 \mathrm{Ba}$ & $5 \mathrm{Cb}$ & $1 \mathrm{Ba}$ & $0 \mathrm{Ba}$ & $10 \mathrm{Aa}$ & $5 \mathrm{Bb}$ \\
\hline BRS 185 & $9 \mathrm{Ca}$ & $3 \mathrm{Db}$ & $1 \mathrm{Ba}$ & $0 \mathrm{Ba}$ & $8 \mathrm{Ca}$ & $2 \mathrm{Db}$ \\
\hline BRS 214 & $7 \mathrm{Da}$ & $3 \mathrm{Db}$ & $0 \mathrm{Cb}$ & $1 \mathrm{Aa}$ & $6 \mathrm{Ea}$ & $2 \mathrm{Db}$ \\
\hline BRS 244 RR & $7 \mathrm{Da}$ & $3 \mathrm{Db}$ & $0 \mathrm{Cb}$ & $1 \mathrm{Aa}$ & $6 \mathrm{Ea}$ & $2 \mathrm{Db}$ \\
\hline BRS 245 RR & $12 \mathrm{Ba}$ & $5 \mathrm{Cb}$ & $0 \mathrm{Ca}$ & $1 \mathrm{Aa}$ & $9 \mathrm{Ba}$ & $5 \mathrm{Bb}$ \\
\hline BRS 246 RR & $5 \mathrm{Ea}$ & $3 \mathrm{Db}$ & $0 \mathrm{Cb}$ & $0 \mathrm{Ba}$ & $4 \mathrm{Ga}$ & $2 \mathrm{Db}$ \\
\hline BRS 255 & $3 \mathrm{Fa}$ & $1 \mathrm{Fb}$ & $0 \mathrm{Ca}$ & $1 \mathrm{Aa}$ & $2 \mathrm{Ia}$ & $1 \mathrm{~Eb}$ \\
\hline BRS 257 & $4 \mathrm{Ea}$ & $2 \mathrm{~Eb}$ & $0 \mathrm{Ca}$ & $0 \mathrm{Ba}$ & $5 \mathrm{Ea}$ & $3 \mathrm{Db}$ \\
\hline BRS 258 & $3 \mathrm{Fa}$ & $2 \mathrm{Ea}$ & $0 \mathrm{Ca}$ & $0 \mathrm{Ba}$ & $3 \mathrm{Ha}$ & $2 \mathrm{Db}$ \\
\hline BRS 261 & $4 \mathrm{Ea}$ & $2 \mathrm{~Eb}$ & $0 \mathrm{Ca}$ & $0 \mathrm{Ba}$ & $6 \mathrm{Ea}$ & $3 \mathrm{Db}$ \\
\hline BRS 262 & $8 \mathrm{Ca}$ & $7 \mathrm{Ba}$ & $0 \mathrm{Ca}$ & $0 \mathrm{Ba}$ & $7 \mathrm{Da}$ & $6 \mathrm{Ab}$ \\
\hline C.V. (\%) Lot & \multicolumn{2}{|c|}{12.37} & \multicolumn{2}{|c|}{23.40} & \multicolumn{2}{|c|}{4.20} \\
\hline C.V. (\%) Sub-Lot & \multicolumn{2}{|c|}{13.45} & \multicolumn{2}{|c|}{30.00} & \multicolumn{2}{|c|}{5.63} \\
\hline
\end{tabular}

${ }^{1}$ Means followed by the same capital letter in each column belong to the same group, according to the Scott-Knott grouping method (1974) at the 5\% probability level.

${ }^{2}$ Means followed by the same non-capital letter in each line do not differ from each other based on the F-test at the 5\% probability level. 
TABLE 4. Malonyl isoflavone content for Twenty one soybean cultivars, before and after a 180 day storage period.

\begin{tabular}{|c|c|c|c|c|c|c|}
\hline \multirow{4}{*}{ Cultivar $^{1}$} & \multicolumn{2}{|c|}{ Daidzin } & \multicolumn{2}{|c|}{ Glicitin } & \multicolumn{2}{|c|}{ Genistin } \\
\hline & \multicolumn{2}{|c|}{ Storage $^{2}$ (days) } & \multicolumn{2}{|c|}{ Storage $^{2}$ (days) } & \multicolumn{2}{|c|}{ Storage $^{2}$ (days) } \\
\hline & 0 & 180 & 0 & 180 & 0 & 180 \\
\hline & \multicolumn{2}{|c|}{$\mathrm{mg} .100 \mathrm{~g}^{-1}$ of flour } & \multicolumn{2}{|c|}{ mg. $100 \mathrm{~g}^{-1}$ of flour } & \multicolumn{2}{|c|}{ mg.100 $\mathrm{g}^{-1}$ of flour } \\
\hline CD 202 & $70 \mathrm{Fa}$ & $56 \mathrm{~Gb}$ & $18 \mathrm{Ba}$ & $7 \mathrm{~Gb}$ & $101 \mathrm{Ea}$ & $84 \mathrm{~Gb}$ \\
\hline CD 206 & $36 \mathrm{Ja}$ & $30 \mathrm{~Kb}$ & $13 \mathrm{Da}$ & $11 \mathrm{Fa}$ & $43 \mathrm{~Kb}$ & $55 \mathrm{Ia}$ \\
\hline CD 208 & $39 \mathrm{Ja}$ & $42 \mathrm{Ia}$ & $8 \mathrm{~Eb}$ & $14 \mathrm{Ea}$ & $94 \mathrm{Fa}$ & $96 \mathrm{Ea}$ \\
\hline CD 213 RR & $40 \mathrm{Ja}$ & $40 \mathrm{Ia}$ & $12 \mathrm{Da}$ & $12 \mathrm{Fa}$ & $70 \mathrm{Ia}$ & $67 \mathrm{Ha}$ \\
\hline CD 214 RR & $87 \mathrm{Da}$ & $89 \mathrm{Ca}$ & $11 \mathrm{Db}$ & $30 \mathrm{Aa}$ & $144 \mathrm{Bb}$ & $158 \mathrm{Ba}$ \\
\hline CD 215 & $63 \mathrm{Ja}$ & $64 \mathrm{Fa}$ & $13 \mathrm{Da}$ & $6 \mathrm{~Gb}$ & $94 \mathrm{Fb}$ & $106 \mathrm{Da}$ \\
\hline CD 216 & $71 \mathrm{Fa}$ & $53 \mathrm{~Gb}$ & $8 \mathrm{Ea}$ & $0 \mathrm{Ib}$ & $78 \mathrm{Ha}$ & $67 \mathrm{Hb}$ \\
\hline CD 217 & $49 \mathrm{Ha}$ & $47 \mathrm{Ha}$ & $30 \mathrm{Aa}$ & $11 \mathrm{Fb}$ & $79 \mathrm{Hb}$ & $94 \mathrm{Ea}$ \\
\hline CD 218 & $52 \mathrm{Ha}$ & $46 \mathrm{Hb}$ & $17 \mathrm{Ba}$ & $8 \mathrm{~Gb}$ & $85 \mathrm{Ga}$ & $88 \mathrm{Fa}$ \\
\hline CD 221 & $33 \mathrm{Ka}$ & $16 \mathrm{Lb}$ & $19 \mathrm{Ba}$ & $5 \mathrm{Hb}$ & $32 \mathrm{La}$ & $31 \mathrm{Ja}$ \\
\hline BRS 184 & $64 \mathrm{Ga}$ & $64 \mathrm{Fa}$ & $18 \mathrm{Ba}$ & $15 \mathrm{~Eb}$ & $72 \mathrm{Ia}$ & $71 \mathrm{Ha}$ \\
\hline BRS 185 & $81 \mathrm{~Eb}$ & $92 \mathrm{Ca}$ & $17 \mathrm{Ca}$ & $18 \mathrm{Da}$ & $91 \mathrm{Fb}$ & $104 \mathrm{Da}$ \\
\hline BRS 214 & $68 \mathrm{Fb}$ & $92 \mathrm{Ca}$ & $14 \mathrm{Db}$ & $18 \mathrm{Da}$ & $88 \mathrm{~Gb}$ & $104 \mathrm{Da}$ \\
\hline BRS 244 RR & $149 \mathrm{Aa}$ & $92 \mathrm{Cb}$ & $19 \mathrm{Ba}$ & $18 \mathrm{Da}$ & $168 \mathrm{Aa}$ & $104 \mathrm{Db}$ \\
\hline BRS 245 RR & $107 \mathrm{Ba}$ & $97 \mathrm{Bb}$ & $19 \mathrm{Ba}$ & $12 \mathrm{Fb}$ & $112 \mathrm{Da}$ & $107 \mathrm{Da}$ \\
\hline BRS 246 RR & $64 \mathrm{~Gb}$ & $79 \mathrm{Da}$ & $7 \mathrm{~Eb}$ & $14 \mathrm{Ea}$ & $93 \mathrm{Fb}$ & $101 \mathrm{Da}$ \\
\hline BRS 255 & $50 \mathrm{Ha}$ & $40 \mathrm{Ib}$ & $2 \mathrm{Fa}$ & $1 \mathrm{Ia}$ & $34 \mathrm{La}$ & $36 \mathrm{Ja}$ \\
\hline BRS 257 & $62 \mathrm{~Gb}$ & $67 \mathrm{Ea}$ & $14 \mathrm{Cb}$ & $24 \mathrm{Ba}$ & $106 \mathrm{~Eb}$ & $112 \mathrm{Ca}$ \\
\hline BRS 258 & $31 \mathrm{Ka}$ & $33 \mathrm{Ga}$ & $7 \mathrm{~Eb}$ & $11 \mathrm{Fa}$ & $59 \mathrm{Ja}$ & $59 \mathrm{Ia}$ \\
\hline BRS 261 & $44 \mathrm{Ib}$ & $61 \mathrm{Fa}$ & $6 \mathrm{~Eb}$ & $20 \mathrm{Ca}$ & $106 \mathrm{~Eb}$ & $117 \mathrm{Ca}$ \\
\hline BRS 262 & $91 \mathrm{Cb}$ & $125 \mathrm{Aa}$ & $11 \mathrm{Db}$ & $25 \mathrm{Ba}$ & $134 \mathrm{Cb}$ & $164 \mathrm{Aa}$ \\
\hline C.V. (\%) Lot & \multicolumn{2}{|c|}{3.88} & \multicolumn{2}{|c|}{12.25} & \multicolumn{2}{|c|}{4.20} \\
\hline C.V. (\%) Sub-Lot & \multicolumn{2}{|c|}{3.95} & \multicolumn{2}{|c|}{13.78} & \multicolumn{2}{|c|}{5.78} \\
\hline
\end{tabular}

${ }^{1}$ Means followed by the same capital letter in each column belong to the same group, according to the Scott-Knott grouping method (1974) at the 5\% probability level.

${ }^{2}$ Means followed by the same non-capital letter in each line do not differ from each other based on the F-test at the 5\% probability level. 
TABLE 5. Glycosil isoflavone content for Twenty one soybean cultivars, before and after a 180 day storage period.

\begin{tabular}{|c|c|c|c|c|c|c|}
\hline \multirow{4}{*}{ Cultivar $^{1}$} & \multirow{2}{*}{\multicolumn{2}{|c|}{$\begin{array}{c}\text { Daidzin } \\
\text { Storage }^{2} \text { (days) }\end{array}$}} & \multirow{2}{*}{\multicolumn{2}{|c|}{$\frac{\text { Glicitin }}{\text { Storage }^{2} \text { (days) }}$}} & \multicolumn{2}{|c|}{ Genistin } \\
\hline & & & & & \multicolumn{2}{|c|}{ Storage $^{2}$ (days) } \\
\hline & 0 & 180 & 0 & 180 & 0 & 180 \\
\hline & \multicolumn{2}{|c|}{$\mathrm{mg} 100 \mathrm{~g}^{-1}$ of flour } & \multicolumn{2}{|c|}{ mg $100 \mathrm{~g}^{-1}$ of flour } & \multicolumn{2}{|c|}{$\mathrm{mg} 100 \mathrm{~g}^{-1}$ of flour } \\
\hline CD 202 & $38 \mathrm{Fa}$ & $31 \mathrm{Fb}$ & $13 \mathrm{Ca}$ & $6 \mathrm{Fa}$ & $59 \mathrm{Ea}$ & $54 \mathrm{Db}$ \\
\hline CD 206 & $20 \mathrm{Ja}$ & $15 \mathrm{Ka}$ & $10 \mathrm{Ea}$ & $5 \mathrm{Fa}$ & $25 \mathrm{Jb}$ & $31 \mathrm{Ga}$ \\
\hline CD 208 & $16 \mathrm{~Kb}$ & $20 \mathrm{Ia}$ & $6 \mathrm{~Gb}$ & $10 \mathrm{Da}$ & $49 \mathrm{Ga}$ & $48 \mathrm{Ea}$ \\
\hline CD 213 RR & $22 \mathrm{Ja}$ & $21 \mathrm{Ia}$ & $10 \mathrm{Ea}$ & $9 \mathrm{Ea}$ & $42 \mathrm{Ha}$ & $40 \mathrm{Fa}$ \\
\hline CD 214 RR & $33 \mathrm{Hb}$ & $37 \mathrm{Ea}$ & $6 \mathrm{~Gb}$ & $21 \mathrm{Aa}$ & $64 \mathrm{Db}$ & $72 \mathrm{Ba}$ \\
\hline CD 215 & $44 \mathrm{Ea}$ & $42 \mathrm{Db}$ & $12 \mathrm{Da}$ & $5 \mathrm{Fb}$ & $66 \mathrm{Da}$ & $70 \mathrm{Ba}$ \\
\hline CD 216 & $46 \mathrm{Ea}$ & $31 \mathrm{Fb}$ & $10 \mathrm{Ea}$ & $0 \mathrm{Hb}$ & $52 \mathrm{Fa}$ & $41 \mathrm{Fb}$ \\
\hline CD 217 & $39 \mathrm{Fa}$ & $32 \mathrm{Fb}$ & $28 \mathrm{Aa}$ & $10 \mathrm{Db}$ & $60 \mathrm{~Eb}$ & $72 \mathrm{Ba}$ \\
\hline CD 218 & $28 \mathrm{Ia}$ & $23 \mathrm{Hb}$ & $12 \mathrm{Da}$ & $6 \mathrm{Fb}$ & $46 \mathrm{~Gb}$ & $53 \mathrm{Da}$ \\
\hline CD 221 & $22 \mathrm{Ja}$ & $8 \mathrm{Lb}$ & $16 \mathrm{Ba}$ & $2 \mathrm{~Gb}$ & $21 \mathrm{Ja}$ & $20 \mathrm{Ha}$ \\
\hline BRS 184 & $36 \mathrm{Ga}$ & $35 \mathrm{Ea}$ & $14 \mathrm{Ca}$ & $11 \mathrm{Db}$ & $46 \mathrm{Ga}$ & $43 \mathrm{Fa}$ \\
\hline BRS 185 & $51 \mathrm{Da}$ & $45 \mathrm{Cb}$ & $14 \mathrm{Ca}$ & $11 \mathrm{Db}$ & $54 \mathrm{Fa}$ & $49 \mathrm{~Eb}$ \\
\hline BRS 214 & $40 \mathrm{Fb}$ & $45 \mathrm{Ca}$ & $9 \mathrm{Fb}$ & $11 \mathrm{Da}$ & $54 \mathrm{Fa}$ & $49 \mathrm{~Eb}$ \\
\hline BRS 244 RR & $67 \mathrm{Ba}$ & $45 \mathrm{Cb}$ & $13 \mathrm{Ca}$ & $11 \mathrm{Db}$ & $76 \mathrm{Ba}$ & $49 \mathrm{~Eb}$ \\
\hline BRS 245 RR & $69 \mathrm{Aa}$ & $53 \mathrm{Bb}$ & $16 \mathrm{Ba}$ & $9 \mathrm{~Eb}$ & $70 \mathrm{Ca}$ & $57 \mathrm{Db}$ \\
\hline BRS 246 RR & $32 \mathrm{Hb}$ & $35 \mathrm{Ea}$ & $6 \mathrm{~Gb}$ & $8 \mathrm{Ea}$ & $47 \mathrm{Ga}$ & $46 \mathrm{Fa}$ \\
\hline BRS 255 & $38 \mathrm{Fa}$ & $25 \mathrm{Hb}$ & $1 \mathrm{Ha}$ & $1 \mathrm{Ha}$ & $22 \mathrm{Ja}$ & $18 \mathrm{Ha}$ \\
\hline BRS 257 & $36 \mathrm{Ga}$ & $38 \mathrm{Ea}$ & $8 \mathrm{Fb}$ & $17 \mathrm{Ba}$ & $61 \mathrm{Ea}$ & $62 \mathrm{Ca}$ \\
\hline BRS 258 & $17 \mathrm{Ka}$ & $18 \mathrm{Ja}$ & $6 \mathrm{Ga}$ & $7 \mathrm{Ea}$ & 35 Ia & $33 \mathrm{Ga}$ \\
\hline BRS 261 & $21 \mathrm{Jb}$ & $27 \mathrm{Ga}$ & $6 \mathrm{~Gb}$ & $13 \mathrm{Ca}$ & $64 \mathrm{Da}$ & $62 \mathrm{Ca}$ \\
\hline BRS 262 & $59 \mathrm{Cb}$ & $75 \mathrm{Aa}$ & $8 \mathrm{Fb}$ & $19 \mathrm{Aa}$ & $88 \mathrm{Ab}$ & $108 \mathrm{Aa}$ \\
\hline C.V. (\%) Lot & \multicolumn{2}{|c|}{4.52} & \multicolumn{2}{|c|}{11.20} & \multicolumn{2}{|c|}{5.67} \\
\hline C.V. (\%) Sub-Lot & \multicolumn{2}{|c|}{5.79} & \multicolumn{2}{|c|}{14.84} & \multicolumn{2}{|c|}{6.78} \\
\hline
\end{tabular}

${ }^{1}$ Means followed by the same capital letter in each column belong to the same group, according to the Scott-Knott grouping method (1974) at the 5\% probability level.

${ }^{2}$ Means followed by the same non-capital letter in each line do not differ from each other based on the F-test at the $5 \%$ probability level

It was stated previously that the loss of seed viability during storage is accompanied by several processes. Nevertheless, the increase of lipid peroxidation and the accumulation of free radicals, which can react with hydrogen peroxides, producing singlet oxygen and hydroxyl radical $\left(\mathrm{OH}^{-}\right)$, toxic to cells (Hendry, 1993) and that are able to injure cell constituents, such as proteins, DNAs and membranes (Hoekstra et al., 1996), are the most accepted theories.

At the same time as the process mentioned above, the ability to prevent, tolerate or repair the attack of free radicals occurs (Nkang et al., 2000). For Hoeskstra et al. (1996), the action of free radicals may be attenuated by a number of removers, e.g. antioxidant activity-like molecules (Rosa et al., 2005), already existent in cells or applied exogenally on seeds (Kikuti et al., 2002). Among these antioxidant molecules, we can name the tocopherol isomers (Vitamin E), beta-carotene, ascorbic acid (vitamin C), glutathione (Rosa et al., 2005; Kikuti et al., 2002) and isoflavonoids (Shahidi and Wanasundara, 1992; Esaki et 
al., 1998; Esaki et al., 1999), some of which are present in soybean seeds.

\section{CONCLUSIONS}

Seed isoflavone contents possess a genotypical distinction, whether the cultivars are conventional or transgenic.

The behavior of isoflavonoid contents and forms is variable among cultivars during non-controlled storage conditions.

\section{REFERENCES}

AGUIRRE, R.; PESKE, S.T. Manual para el beneficio de semillas. Cali: Centro Internacional de Agricultura Tropical, 1992. 247p.

AGUIAR, C.L. Isoflavonas de soja e propriedades biológicas. Boletim do Centro de Pesquisa de Processamento de Alimentos, v.20, n.2, p. 323-334, 2002.

ÁVILA, M.R. Teores de óleo, proteínas e isoflavonas, qualidade das sementes e utilização de bioestimulante em cultivares de soja (Glycine max (L.) Merrill). 2004, $107 \mathrm{p}$. Tese de Doutorado - Universidade Estadual de Maringá, Maringá, 2004.

BASAVARAJAPPA, B.S.; SHETTY, H.S.; PRAKASH, H.S. Membrane deterioration and other biochemical changes, associated with accelerated ageing of maize seeds. Seed Science and Technology, v.19, n.2, p.279286, 1991.

BERHOW, M.A. Modern analytical techniques for flavonoid determination. In: BUSLIG, B.S.; MATHEY, J.A. (Ed.). Flavonoids in the living cell. New York: Klusher Academic, 2002. p.61-76.

BEWLEY, J.D.; BLACK, M. Seeds: physiology of development and germination. New York: Plenum Press, 1985, 367p.

BRACCINI, A.L.; BRACCINI, M.C.L.; SCAPIM, C.A. Mecanismos de deterioração de sementes: Aspectos bioquímicos e fisiológicos. Informativo ABRATES. v.11, n.1, p.10-15, 2001.

BRASIL. Ministério da Agricultura e Reforma Agrária. Regras para análise de sementes. Brasília: SNDA/ DNDV/CLAV, 1992. 365p.

CARRÃO-PANIZZI, M.C. Isoflavonóides em soja
(Glycine max (L.) Merril): variabilidade genética e ambiental de cultivares e efeito no processamento do extrato solúvel. 1996. 123p. Tese de Doutorado. Universidade Estadual de Londrina, Londrina, 1996.

CARRÃO-PANIZZI, M.C.; SIMÃO, A.S.; KIKUCHI, A. Efeitos de genótipos, ambientes e de tratamentos hidrotérmicos na concentração de isoflavonas agliconas em grãos de soja. Pesquisa Agropecuária Brasileira, v.38, n.8, p.897-902, 2003.

COWARD, L.; BARNES, N.C.; SETCHELL, K.D.R.; BARNES, S. Genistein, daidzein, and their b-glycoside conjugates: antitumor isoflavones in soybean foods from American and Asian diets. Journal of Agricultural and Food Chemistry, v.41, n.11, p.1961-1967, 1993.

DELOUCHE, J.C. Physiological changes during storage that affect soybean seed quality. In: SINCLAIR, J.B.; JACKOBS, J.A. (Ed.). Soybean seed quality and stand establishment. (Intsoy, 22). s.1.: Intsoy, 1982. p.57-66.

DELOUCHE, L.E.; BASKIN, E.E. Accelerated aging technique for predicting the relative storability of seeds lots. Seed Science and Technology, v.1, n.2, p.427-452. 1973.

DUKE, S.O.; RIMANDO, A.M.; PACE, P.F.; REDDY, N.K.; SMEDA, R.J. Isoflavone, glyphosate, and aminomethylphosphonic acid levels in seeds of glyphosate-treated, glyphosate-resistant soybean. Journal of Agriculture and Food Chemistry, v.51, n.1, p. 340344, 2003.

ESAKI, H.; WATANABE, S.; ONOZAKI, H.; KAWAKISHI, S.; OSAWA, T. Formation mechanism for potent antioxidative O-dihydroxyisoflavones in soybeans fermented with Aspergillus saitoi. Bioscience, Biotechnology and Biochemistry, v.63, n.9, p.851-858, 1999.

ESAKI, H.; ONOZAKI, H.; MORIMITSU, Y. Potent antioxidative isoflavones isolate from soybeans fermented with Aspergillus saitoi. Journal Bioscience, Biotechnology, Biochemistry, v.62, n.4, p.740-746, 1998.

FRANÇA NETO, J.B.; KRZYZANOWSKI, F.C.; COSTA, N.P. Metodologia do teste de tetrazólio em sementes de soja. In: KRZYZANOWSKI, F. C.; VIEIRA, R. D.; FRANÇA NETO, J. B. (Eds.). Vigor de sementes: conceitos e testes. Londrina: ABRATES, 1999. Cap.8.5, p.1-28.

FRANÇA NETO, J. B.; KRYZANOWSKI, F. C.; SILVA, W. R. O teste de tetrazólio em sementes de soja. 
Londrina: EMBRAPA-CNPSo, 1998. 72p. (Documentos, 116).

FRANÇA NETO, J. B.; HENNING, A. A. Qualidade fisiológica e sanitária de sementes de soja. Londrina: EMBRAPA-CNPSo, 1984. 39p. (Circular Técnica, 9).

FUKUTAKE, M.; TAKAHASHI, M.; ISHIDA, K.; KAWAMURA, H.; SUGIMURA, T.; WAKABAYASHI, K. Quantification of genistein and genistin in soybeans and soybean products. Food and Chemical Toxicology, v.34, n.5, p.457-461, 1996.

HAMPTON, J.G.; TEKRONY, D.M. (ed.). Handbook of vigour test methods. Zürich: International Seed Testing Association. 3 ${ }^{\mathrm{a}}$ ed., 1995. 117p.

HENDRY, G.A.F. Oxygen, free radical processes and seed longevity. Seed Science Research, v.3, n.2, p.141153, 1993.

HOEKSTRA, F.A.; WOLKERS, W.F.; BUTTINK, J.; GOLOVINA, E.A. Desiccation tolerance and long term structural stability. In: INTERNATION WORKSHOP ON SEEDS: basic and applied aspects of seed biology. Proceeding... Reading: University of Reading, 1996. p.1-12.

JAWORSKI, E.G. Mode of action of N-phosphonomethylglycine: Inhibition of aromatic amino acid biosynthesis. Journal of Agriculture and Food Chemistry, v.20, n. 6, p.1195-1198, 1972.

KIKUTI, A.L.P.; GUIMARÃES, R.M.; PINHO, E.V.R.V.; OLIVEIRA, J.A. Aplicação de antioxidante em sementes de cafeeiro (Coffea arábica L.) visando à preservação da qualidade. Ciência e Agrotecnologia, v.26, n.4, p.663-672, 2002.

KRZYZANOWSKI, F.C.; WEST S.H.; FRANÇA NETO, J.B. Influência do conteúdo de isoflavonas sobre a qualidade fisiológica da semente de soja. In: CONGRESSO BRASILEIRO DE SEMENTES, 7. Brasília, 2001. Anais... Londrina: Embrapa - CNPSo, 2003. p.47.

KRZYZANOWSKI, F.C.; FRANÇA NETO, J.B.; HENNING, A.A. Relato dos testes de vigor disponíveis para as grandes culturas. Informativo Abrates, v.1, n.2, p.15-50, 1991.

KUDOU, S.; FLEURY, Y; WELTI, D.; MAGNOLATO, D.; UCHIDA, T.; KITAMURA, K., OKUBO, K. Malonil isoflavone glycosides in soybeans seeds (Glycine max (L.) Merrill). Agriculture Biology Chemistry, v.55, n.9, p. 2227-2233, 1991.

MARCOS FILHO, J. Fisiologia de sementes de plantas cultivadas. Piracicaba: Fealq, 2005. 495p.

MARCOS FILHO, J. Teste de envelhecimento acelerado. In: KRZYZANOWSKI, F.C.; VIEIRA, R.D.; FRANÇA NETO, J.B. (Ed.). Vigor de sementes: conceitos e testes. Londrina: Abrates, 1999. 3-21p.

MIYAZAWA, M.; SAKANO, K.; NAKAMURA, S.; KOSAKA, H. Antimutagenic activity of isoflavones from soybean seeds (Glycine max Merrill). Journal of Agricultural and Food Chemistry, v.47, n.4, p. 13461349, 1999.

MURPHY, P.A. Phytoestrogen content of processed soybean products. Food Technology, v.36, n.1, p.60-64, 1982.

NAIM, M.; GESTETNER, B.; ZILKAH, S.; BIRK, Y.; BONDI, A. Soybean isoflavones: characterization, determination, and antifungal activity. Journal of Agricultural and Food Chemistry, v.22, n.5, p.806-810, 1974.

NKANG, A.; OMOKARO, D.; EGBE, A. Effects of desiccation on the lipid peroxidation and activities of peroxidase and polyphenoloxidase in seeds of Telfairia occidentalis. Seed Science and Technology, v.28, n.1, p.1-9, 2000.

PARK, Y.K.; AGUIAR, C.L.; ALENCAR, S.M.; SCAMPARINI, A.R.P. Avaliação do teor de isoflavonas em soja Brasileira. Ciência e Tecnologia de Alimentos, v.3, n.3, p.156-160, 2001.

PELICICE, F.M.; DIETRICH, S.M.C.; BRAG, M.R. Phytoalexin response of fifteen brazilian soybean cultivars. Revista Brasileira de Fisiologia Vegetal, v.12, n.1, p.45-53, 2000.

POPINIGS, F. Fisiologia da Semente. 2a ed. Brasília, AGIPLAN, 1985. 289p.

ROSA, S.D.V.F.; PINHO, E.V.R.V.; VIEIRA, E.S.N.; VEIGA, R.D.; VEIGA, A.D. Enzimas removedoras de radicais livres e proteínas $L e a$ associadas à tolerância de sementes de milho à alta temperatura de secagem. Revista Brasileira de Sementes, v.27, n.2, p.91-101, 2005.

SCOTT, A.; KNOTT, M. Cluster-analysis method for grouping means in analysis of variance. Biometrics, v.30, p.507-512, 1974.

SHAHIDI, F.; WANASUNDARA, P.K.J.P.D. Pnenolic antioxidants. Critical Reviews in Food Science and Nutrition, v.32, n.1, p.67-103, 1992.

TAIZ, L.; ZEIGER, E. Trad.: SANTARÉM, E.R. 
Fisiologia vegetal. 3ª . ed. Porto Alegre: Artmed, 2004. $613 p$.

VIEIRA, R.D.; CARVALHO, N.M. Teste de vigor em sementes. Jaboticabal: FUNEP, 1994. 164p.

VILLA, L.G.; ROSA, G.; MERINO, G. Secagem e armazenamento de sementes de soja em silos. In: SEMINÁRIO NACIONAL DE PESQUIISA DE SOJA, 1, Londrina, 1978. Anais. Londrina: EMBRAPA/CNPSo, 1979. v.2, p.279.
YOSHIKAWA, M.; YAMAUCHI, K.; MASAGO, $\mathrm{H}$. Glyceollin: its role in restricting fungal growth in resistant soybean hypocotyls infected with Phytophthora megasperma var. sojae. Phytopathology Plant Pathology, v.12, n.1, p.73-82, 1978.

WILSON, D.O.; MCDONALD, M.B. The lipid peroxidation model of seed ageing. Seed Science and Technology, v.14, n.2, p.269-300, 1986. 